\title{
Effect of very short-term inpatient cardiac rehabilitation programs in acute myocardial infarction patients treated with primary percutaneous coronary intervention
}

\author{
Dejan Spiroski ${ }^{1}$, Mojsije Andjić ${ }^{1}$, Ivana Burazor ${ }^{1}$, Slavica Stevović ${ }^{1}$, Zoran Ćosić ${ }^{1}$, Olivera llić \\ Stojanović ${ }^{1}$, Milica Lazovićc ${ }^{1,2}$, Ana Djordjević Dikić2, ${ }^{3}$, Marija Zdravković ${ }^{4}$, Dragan Lovićs, \\ Branko Beleslin', 3 \\ ${ }^{1}$ Institute for rehabilitation, Belgrade, Serbia, ${ }^{2}$ Belgrade University School of Medicine, Belgrade, Serbia, ${ }^{3}$ Clinic \\ for Cardiology Clinical Centre of Serbia, Belgrade, Serbia, ${ }^{4}$ Hospital Medical Center Bežanijska kosa, Belgrade, \\ Serbia, ${ }^{5}$ Clinic for Internal Disease Inter Medica, Niš, Serbia
}

Abstract

Background: Exercise-based rehabilitation is an important part of treatment patients following acute myocardial infarction (MI). However, data are scarce on the efffects of very short-term exercise programs in patients with acute $\mathrm{MI}$ treated with primary percutaneous coronary intervention ( $\mathrm{pPCl}$ ). The aim of the study was to evaluate the effects of very short-term exercise training on cardiopulmonary exercise testing (CPET) parameters in patients suffering acute MI treated with $\mathrm{pPCl}$.

Methods: We studied 40 consecutive patients with MI treated with $\mathrm{pPCl}$ reffered for rehabilitation to our institution. The study population consisted of 39 men and 1 women (age 50,60 $\pm 8,40$ years, left ventricular ejection fraction $53,05 \pm 6,74 \%$ ), who participated in 3-week clinical cardiac rehabilitation program. The program consisted of cycling for 7 times/week, and daily walking for $45 \mathrm{~min}$ at intensity of $70-80 \%$ of the individual maximal heart rate. All patients performed symptom-limited CPET on a bicycle ergometer with a ramp protocol of $10 \mathrm{w} / \mathrm{min}$. The CPET also performed after cardiac rehabilitation programs.

Results: After 3 weeks of exercise-based cardiac rehabilitation program improved exercise tolerance as compared to baseline (peak workload $111,50 \pm 15,07$ vs $129,00 \pm 12,77$ watts, respectively, $p<0,001)$, as well as peak respiratory exchage ratio $(1,02 \pm 0,10$ vs $1,08 \pm 0,13$, respectively, $p<0,05)$. Peak systolic blood pressure, heart rate, peak and after 1 minute of rest were also improved. Most importantly, peak VO2 $(18,17 \pm 3,30$ vs $20,64 \pm 3,27 \mathrm{ml} / \mathrm{kg} / \mathrm{min}$, respectively, $p<0,001)$, peak VCO2 $(1,65 \pm 0,28$ vs $1,96 \pm 0,25 \mathrm{ml} / \mathrm{kg} / \mathrm{min}$, respectively, $p<0,001)$, peak ventilation $(48,61 \pm 10,70 \mathrm{vs}$ $57,27 \pm 9,85 \mathrm{~L} / \mathrm{min}$, respectively, $p<0,001)$ and peak oxygen pulse $(14,16 \pm 2,62 \mathrm{vs} 60.18 \pm 14.19 \mathrm{ml} /$ beat, respectively, $\mathrm{p}<0,05)$ were also improved. No major adverse cardiac events were noted during the rehabilitation program.

Conclusion: Very short-term exercise training in patients with acute $\mathrm{MI}$ treated with $\mathrm{pPCl}$ is safe and improves functional capacity, as well as test duration, work load and heart rate response.

Key Words cardiac pulmonary exercise testing, exercise training, cardiac rehabilitation, myocardial infarction

\section{Background}

ardiovascular prevention and rehabilitation critically depend on physical activity and exercise training. ${ }^{1,2}$ Exercise-based rehabilitation leads to reduction in all-cause mortality and the risk of reinfarction. Also, it modulates other risk factors and improves exercise-based capacity and quality of life after myocardial infarction (Ml). ${ }^{3,4}$ Aerobic exercise consists of three major components, that include intensity, duration and frequency of exercise sessions. ${ }^{3,5}$ The intensity of exercise training prescription is a key issue in cardiac rehabilitation program. It has not been universaly shown that exercise-based rehabilitation leads to improvement in exercise capacity and reduction in the incidence of cardiac events in patients following acute MI. ${ }^{1,6}$

Cardiopulmonary exercise testing (CPET) using ramp incremental protocol is the gold standard for exercise intensity assessment and prescription in patients with cardiovascular disease. It has been advocated that this test should be performed, where available, in patients before and after cardiac rehabilitation (CR) program, ${ }^{7,8,}$ 
${ }^{9}$ in order to quantify exercise capacity, chronotropic and inotropic responses to exercise, as well as to detect presence and severity of arrhythmias and inducible myocardial ischemia. ${ }^{10}$

Aerobic exercise training in cardiac patients is usually performed using the constant work-rate (CWR) exercise. ${ }^{5}$ The exercise intensity influences the metabolic and gas exchange responses to CWR. A number of studies have documented improvements in functional capacity after cardiac rehabilitation programs in patients with stable coronary artery disease and myocardial infarction who underwent percutaneous coronary intervention $(\mathrm{PCl})$. Most studies have reported increase in peak $\mathrm{VO}_{2}$, in the range of 14 to $31 \%$ after exercise training. ${ }^{11} \mathrm{Al}-$ most all previous studies have investigated effects of exercise-based rehabilitation that lasted for at least six weeks. As to our knowledge, there are no studies that investigated effects of very short-term exercise programs in patients suffering acute $\mathrm{MI}$ treated with primary $\mathrm{PCl}(\mathrm{pPCl})$.

Therefore, the aim of our study was to evaluate effect of very short-term ( 3 weeks) exercise training on CPET parameters in patients suffering acute $\mathrm{MI}$ treated with $\mathrm{pPCl}$.

\section{Methods}

Study population. We studied 40 consecutive patients admitted to the Institute for rehabilitation Belgrade for exercise-based rehabilitation program who met all of the following criteria: 1) previous acute MI treated with $\mathrm{pPCl}, 2$ ). ability to perform a symptom-limited CPET, and 3) signed informed consent. Patients were exluded if they had previous $\mathrm{MI}$ or revascularization (other than for index event), unstable angina, significant provocable ischemia, complex ventricular arrhythmias, primary valvular disease, severe peripheral vascular disease, severe chronic obstructive pulmonary disease, neuromuscular disease or orthopedic limitation. Study design was approved by the Belgrade University School of Medicine Ethics Committee, and written information and consent were obtained from all patients prior to any study procedure.

Cardiac rehabilitation program. Patients took part in a comprehensive CR program seven times a week for a period of three weeks. The program included exercise training, information sessions, dietary counseling, psychosocial support and smoking cessation. There were two training sessions daily, each of 45 minutes duration. First training session was performed in the morning, which included warm up and cool-down period and a 30-min training phase (aerobic interval training consisting of 3 minutes exercise and 3 minutes rest on a cycle ergometer). The second session was performed in the afternoon, in which aerobic training included walking on the flat surface (continuous training) and walking up stairs (interval training). The training intensity was aimed to be between $60-80 \%$ of peakVO 2 as assessed by CPET.

Cardiopulmonary exercise testing. Symptom-limited CPET was performed on a bicycle ergometer (Ergometer
DX1 and Ergometer AX1, Kettler, Ense-Parsit, Germany) with a ramp protocol of $10 \mathrm{w} / \mathrm{m}$ (workload was increased by $10 \mathrm{w} / \mathrm{m}$ ). The aim was to achieve a maximal effort with a respiratory exchange ratio $>1,05$. Blood pressure was measured manually at rest and every one-minute during the entire testing. The electrocardiogram and heart rate (HR) were monitored at rest and throughout exercise all the time. Breathe-by breath respiratory gas exchange parameters were measured by a computerized metabolic cart (Cardiovit AT 104 PC, Shiller, Baar, Switzerland). CPET was performed prior to the start of program and immediately after the end of three week exercise-based rehabilitation program. The following CPET parameters were measured: 1) peak $\mathrm{VO}_{2}$ expressed in $\mathrm{ml} / \mathrm{kg} / \mathrm{min}$ and predicted percentage, 2) slope of minute ventilation vs. carbon dioxide production (VE/ $\left.V_{\left(O_{2}\right.}\right), 3$ ) peak respiratory exchange ratio (RER), defined as the peak $\mathrm{VCO}_{2}$ /peak $\mathrm{VO}_{2}$ ratio, 4) peak $\mathrm{VCO}_{2}, 5$ ) peak oxygen pulse, defined as peak $\mathrm{VO}_{2}$ divided by peak $\mathrm{HR}$ and expressed in $\mathrm{ml} /$ beat $\left(\mathrm{O}_{2}\right.$ pulse), 6$)$ ventilatory anaerobic threshold detection (VAT), using the V-slope method, 7) maximum ventilation (VE max), 8) peak end-tidal $\mathrm{CO}_{2}$ partial pressure, $(\mathrm{PET} \mathrm{CO} 2), 9$ ) peak $\left.\mathrm{HR}, 10\right) \mathrm{HR}$ recovery, 11) test duration, 12) peak work load , 13) peak systolic arterial blood pressure (SBP), and 14) peak diastolic blood pressure (DBP).

Echocardiography. Complete echocardiographic evaluations were performed using dedicated echocardiographic equipment (Vivid 3, General Electric, Little Chalfont, UK). Left ventricular ejection fraction (EF) was calculated using Simpson biplane method. Measurements were made just before the start and 3 weeks after the rehabilitation program.

Laboratory. Blood for biochemical analysis was drawn after 12 hours fasting period. The following serum parameters were measured: total cholesterol, highdensity lipoprotein (HDL), low-density lipoprotein (LDL), triglycerides, fasting glucose, urea, creatinine, sodium, potassium, red blood cells, a high-sensitivity C-reactive protein (hsCRP).

Measurements were made just before start and after termination of inpatient rehabilitation program using biochemical analyzer (Roche 902, Basel, Switzerland).

Statistical analysis. The data were entered into an electronic database (Access, Microsoft) and analyzed using the SPSS 16.0 software (SPSS Inc., Chicago, USA). Continuous variables were expressed as mean and standard deviations. Categorical variables were expressed as percentages. The variables tested prior to the start of program and immediately after the end of three-week exercise-based rehabilitation program were analyzed and compared using analysis of variance (ANOVA). Dichotomous variables were analyzed using the $c^{2}$ test and Fisher's exact test, and continuous variables were analyzed using the $t$-test. The level of statistical significance was set a two tailed probability value of $<0,05$.

\section{Results}

Demographic data and comorbidities. Basic demographic data for the patients included in the study are 
Table 1. Baseline demographic data and comorbidities

\begin{tabular}{|ll|}
\hline Sex, male (\%) & $39 / 40(97,5 \%)$ \\
\hline Age, years & $50,60 \pm 8,40$ \\
\hline Diabetes, $\mathrm{n}(\%)$ & $8 / 40(20 \%)$ \\
\hline Hypertension, $\mathrm{n}(\%)$ & $24 / 40(60 \%)$ \\
\hline Hyperlipoproteinemia, n (\%) & $37 / 40(92,5 \%)$ \\
\hline Obesity, n (\%) & $17 / 40(42,5 \%)$ \\
\hline Smoking, n (\%) & $34 / 40(85 \%)$ \\
\hline Family burden, n (\%) & $30 / 40(75 \%)$ \\
\hline
\end{tabular}

shown in Table 1. Briefly, the study population consisted of 39 men and 1 women, mean age of $50,60 \pm 8,40$ years. More than two-thirds of patients suffered acute $\mathrm{MI}$ of the inferior wall. All patients had acute MI with ST segment elevation and received $\mathrm{pPCl}$ within 12 hours of typical chest pain. There were $34 / 40$ (85\%) of patients who actively smoke. Comorbidities are detailed in the Table 1 . Patients received contemporary concomitant medical treatment, that is $40 / 40(100 \%)$ patients were on dual antiplatelet therapy, 38/40 (95\%) received betablockers, $31 / 40(77,5 \%)$ were on angiotensin converting enzyme inhibitor or angiotensin receptor blocker, and $39 / 40(97,5 \%)$ was on statin. Exercise-based rehabilitation program was started $34,2 \pm 10,9$ days after acute MI.

CPET parameters. All CPET parameters were examined before and after completed CR programs (Table 2). After 3 weeks of exercise-based cardiac rehabilitation program improved exercise tolerance as compared to

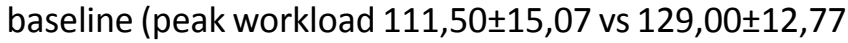
watts, respectively, $p<0,001)$, as well as peak respiratory exchage ratio $(1,02 \pm 0,10$ vs $1,08 \pm 0,13$, respectively, $p<0,05)$. Peak systolic blood pressure, heart rate, peak and after 1 minute of rest were also improved. Most importantly, peak VO2 $(18,17 \pm 3,30$ vs $20,64 \pm 3,27 \mathrm{ml} /$ $\mathrm{kg} / \mathrm{min}$, respectively, $\mathrm{p}<0,001)$, peak VCO2 $(1,65 \pm 0,28$ vs $1,96 \pm 0,25 \mathrm{ml} / \mathrm{kg} / \mathrm{min}$, respectively, $p<0,001)$, peak ventilation $(48,61 \pm 10,70$ vs $57,27 \pm 9,85 \mathrm{~L} / \mathrm{min}$, respectively, $p<0,001)$ and peak oxygen pulse $(14,16 \pm 2,62$ vs $60.18 \pm 14.19 \mathrm{ml} /$ beat, respectively, $p<0,05)$ were also improved.

Interestingly, exercise electocardiography indicated the presence of ischemia in five patients $(12,5 \%)$ before and one patients $(2,5 \%)$ after CR program. There were no major adverse cardiac events during rehabilitation program.

Laboratory and clinical data. We noticed a statistically significant difference only at hsCRP values $(7,27 \pm 5,73$ vs $4,96 \pm 5,50$, respectively, $p<0,01)$ comparing a start and three-week measurement.

There was significant differences in body mass index $(28,82 \pm 4,41$ vs $28,50 \pm 4,13$, respectively, $p<0,001)$. Left ventricular ejection fraction recorded no significant difference $(53,05 \pm 6,74$ vs $53,83 \pm 6,59, N S)$ before and after CR program (Table 3 ).

\section{Discussion}

Main finding of our study is that very short-term (three weeks daily, 21 training sessions) exercise training in patients with acute $\mathrm{MI}$ treated with $\mathrm{pPCl}$ is safe and improves functional capacity. Very short-term daily exercise training in these patients improves also peak work load and chronotropic parameters evaluated during CPET. This suggests that the effects of physical training depend on the total number of sessions regardless of the length of interval training.

Previuos studies indicated that values of peak $\mathrm{VO}_{2}$ on entry in cardiac rehabilitation program are relatively low, particularly in women. It has been shown that peak $\mathrm{VO}_{2}$ measured in 2896 patients prior to cardiac rehabilitation program, was higher in men than women:

Table 2. Cardiopulmonary exercise test parameters (at start and 3 weeks after exercise rehabilitation)

\begin{tabular}{|c|c|c|c|}
\hline & start & 3 weeks & $\begin{array}{c}p \text { value } \\
\text { start } / 3 \text { weeks }\end{array}$ \\
\hline Peak work load (W) & $111,50 \pm 15,07$ & $129,00 \pm 12,77$ & $<0,001$ \\
\hline Test duration (min) & $11,15 \pm 1,87$ & $12,9 \pm 2,36$ & $<0,001$ \\
\hline Peak SBP (mmHg) & $167,50 \pm 19,01$ & $177,75 \pm 16,09$ & $<0,001$ \\
\hline Peak DBP (mmHg) & $93,75 \pm 11,13$ & $97,25 \pm 9,99$ & $>0,05$ \\
\hline HR at rest (bpm) & $74,40 \pm 11,80$ & $74,73 \pm 10,20$ & $>0,05$ \\
\hline Peak HR (bpm) & $116,28 \pm 15,82$ & $124,90 \pm 17,75$ & $<0,001$ \\
\hline HR recovery $1 \mathrm{~min}(\mathrm{bpm})$ & $18,73 \pm 9,29$ & $22,18 \pm 9,11$ & $<0,05$ \\
\hline Peak RER & $1,02 \pm 0,10$ & $1,08 \pm 0,13$ & $<0,05$ \\
\hline VO2 at rest $(\mathrm{ml} / \mathrm{kg} / \mathrm{min})$ & $4,44 \pm 0,95$ & $4,72 \pm 1,32$ & $<0,05$ \\
\hline VO2 at VAT $(\mathrm{ml} / \mathrm{kg} / \mathrm{min})$ & $12,67 \pm 2,27$ & $13,65 \pm 2,78$ & $>0,05$ \\
\hline Peak VO2 (ml/kg/min) & $18,17 \pm 3,30$ & $20,64 \pm 3,27$ & $<0,001$ \\
\hline Peak VCO2 (ml/kg/min) & $1,65 \pm 0,28$ & $1,96 \pm 0,25$ & $<0,001$ \\
\hline Peak PET CO2 (mmHg) & $38,07 \pm 4,12$ & $38,08 \pm 3,64$ & $>0,05$ \\
\hline VE/VCO2 slope & $27,56 \pm 3,60$ & $26,66 \pm 2,54$ & $>0,05$ \\
\hline Peak oxygen pulse (ml/beat) & $14,16 \pm 2,62$ & $14,90 \pm 2,56$ & $<0,05$ \\
\hline Peak VE (L/min) & $48,61 \pm 10,70$ & $57,27 \pm 9,85$ & $<0,001$ \\
\hline
\end{tabular}

Abbreviations: DBP, diastolic blood pressure; HR, heart rate; PET, peak end-tidal; RER, respiratory exchange ratio; SBP, systolic blood pressure; VE, ventilation; VAT, ventilatory anaerobic threshold. 
Table 3. Laboratory and clinical data (at start and 3 weeks after exercise rehabilitation)

\begin{tabular}{|c|c|c|c|}
\hline Laboratory & start & 3 weeks & $p$ value start/ 3 week \\
\hline Glucose (mmol/L) & $5,37 \pm 0,66$ & $4,89 \pm 0,41$ & $>0,05$ \\
\hline Total cholesterol (mmol/L) & $3,93 \pm 0,86$ & $3,79 \pm 0,68$ & $>0,05$ \\
\hline LDL cholesterol (mmol/L) & $2,32 \pm 0,76$ & $2,76 \pm 0,81$ & $>0,05$ \\
\hline HDL cholesterol (mmol/L) & $0,84 \pm 0,21$ & $0,82 \pm 0,20$ & $>0,05$ \\
\hline Triglycerides (mmol/L) & $1,74 \pm 0,76$ & $1,76 \pm 0,71$ & $>0,05$ \\
\hline Creatinine $(\mu \mathrm{mol} / \mathrm{L})$ & $83,72 \pm 13,23$ & $83,75 \pm 13,58$ & $>0,05$ \\
\hline Urea $(\mu \mathrm{mol} / \mathrm{L})$ & $6,32 \pm 1,22$ & $5,96 \pm 1,60$ & $>0,05$ \\
\hline $\operatorname{RBCs}\left(10^{12} / \mathrm{L}\right)$ & $4,59 \pm 0,40$ & $4,53 \pm 0,38$ & $>0,05$ \\
\hline $\mathrm{Na}(\mathrm{mmol} / \mathrm{L})$ & $142,08 \pm 1,74$ & $142,07 \pm 1,69$ & $>0,05$ \\
\hline $\mathrm{K}(\mathrm{mmol} / \mathrm{L})$ & $4,57 \pm 0,29$ & $4,65 \pm 0,22$ & $>0,05$ \\
\hline $\mathrm{hsCRP}$ (mg/L) & $7,27 \pm 5,73$ & $4,96 \pm 5,50$ & $<0,01$ \\
\hline \multicolumn{4}{|l|}{ Clinical data } \\
\hline $\mathrm{BMI}\left(\mathrm{kg} / \mathrm{m}^{2}\right)$ & $28,82 \pm 4,41$ & $28,50 \pm 4,13$ & $<0,001$ \\
\hline LVEF (\%) & $53,05 \pm 6,74$ & $53,83 \pm 6,59$ & $>0,05$ \\
\hline
\end{tabular}

$(9,3 \pm 6,1 \mathrm{ml} / \mathrm{kg} / \mathrm{min}$ vs $14,5 \pm 3.9 \mathrm{ml} / \mathrm{kg} / \mathrm{min} ; \mathrm{p}<0,0001){ }^{12}$ Previous studies have reported that in patients following acute $\mathrm{MI}$, peak $\mathrm{VO}_{2}$ and $\mathrm{VO}_{2}$ at anaerobic threshold increase between $7 \%$ and $54 \%$ after a period of few weeks of exercise training. ${ }^{3}$ Lack of improvement in exercise capacity after an exercise training program is a predictor of poor prognosis. The study authored by Savage et al, which included 385 patients in CR program, showed that $81(21 \%)$ patients failed to improve peak $\mathrm{VO}_{2}$ after termination of the program.13 Similarly, patients with peak $\mathrm{VO}_{2}$ bellow $10 \mathrm{ml} / \mathrm{kg} / \mathrm{min}$ had a poor prognosis, and those above $18 \mathrm{ml} / \mathrm{kg} / \mathrm{min}$ had a good prognosis. ${ }^{14}$ Therefore, the increase in peak $\mathrm{VO}_{2}$, after exercise training might contribute to better survival in patients following Ml. Our data demonstrate an increase of $13,5 \%$ in peak $\mathrm{VO}_{2}$ and $7,7 \%$ of $\mathrm{VO}_{2}$ at anaerobic threshold. It is worth emphasizing that $\mathrm{VO}_{2}$ at anaerobic threshold is independent of patient's motivation, and it is a good parameter to evaluate the training effect. ${ }^{3}$

In accordance with our findings is the results of one meta-analysis ${ }^{15}$ which have reported an average increase in peak $\mathrm{VO}_{2}$ of 2 to $22 \%$ following exercise training program. Study by Gremeaux et al. also used three week exerecise-training program, but with less frequent training sessions ( 3 days a week, total 15 sessions). This study showed marked improvement in peak $\mathrm{VO}_{2}$ $(+14,25 \%)$ and peak workload $(+30,8 \%)$, after completion of the program as compared to baseline. ${ }^{16}$ Similarly, Bjarnason et al. have showed in a study which included 262 patients with coronary artery disease $\mathrm{e}^{17}$ that the maximum exercise workload had improved significantly $(105,3 \pm 32,3$ vs. $123,9 \pm 37,3$ watts, $p<0,001)$ after a four week, three times per week, ambulatory CR program.

Six electronic databases were searched to identify studies investigating resistance training, coronary heart disease and physical function. Improvements in peak oxygen uptake (WMD: $0.61,95 \% \mathrm{Cl}: 0.20-1.10$ ), peak work capacity (SMD: 0.38, 95\% Cl: 0.11-0.64) and muscular strength (SMD: $0.65,95 \% \mathrm{Cl}: 0.43-0.87$ ) significantly favoured resistance training in combination with aerobic training over aerobic training only with moderate quality evidence. There was no evidence of a diffe- rence in effect when comparing resistance training and aerobic training. Resistance training in combination with aerobic training is more beneficial than aerobic training alone for improving physical function. ${ }^{18}$

Longer, but less intensive, exercise rehabilitation programs may also improve functional capacity following acute MI. In the study that included 94 patients following acute $\mathrm{Ml}$ treated with $\mathrm{pPCl}$, exercise sessions were prescribed for 3 months, 3 day a week (total of 36 sessions), and significant improvement in peak $\mathrm{VO}_{2}$ was noted at the end of rehabilitation program as compared to baseline $(20 \pm 4$ vs. $14 \pm 4 \mathrm{ml} / \mathrm{kg} / \mathrm{min}$, $p<0,001)$, as well as in peak workload $(p<0.001) .{ }^{19}$ Lavie and Milani ${ }^{20}$ have reported that exercise training program can be also improve heart rate recovery (- 10 to $12 \%)$, peak anaerobic threshold ( +10 to $15 \%)$, as well as metabolic parameters including total cholesterol $(-5 \%)$, triglycerides (-15\%), HDL-cholesterol ( +5 to $10 \%)$, and LDL - cholesterol (-3\%). ${ }^{20}$ Our study showed modest improvements in metabolic parameters that failed to reach statistical significance.

Overall, 359 patients who have suffered acute $\mathrm{MI}$, and were referred for CR after PCl from 2010 to 2015 and underwent an exercise tolerance test before and after phase II CR were included in this study. The patients were divided into two groups: obese group with body mass index (BMI) $\geq 25 \mathrm{~kg} / \mathrm{m}^{2}$ ( $\mathrm{n}=170$; age, $54,32 \pm 9$, 98 years; $\mathrm{BMI}, 27,52 \pm 2,92 \mathrm{~kg} / \mathrm{m}^{2}$ ) and non-obese group with BMI $<25 \mathrm{~kg} / \mathrm{m}^{2}(\mathrm{n}=189$; age, $59,12 \pm 11,50$ years; $\mathrm{BMI}$ $\left.22,86 \pm 2,01 \mathrm{~kg} / \mathrm{m}^{2}\right)$. There were significant changes in resting heart rate $\left(\mathrm{HR}_{\text {rest }}\right)$ before and after $\mathrm{CR}$ between the obese and non-obese groups (before $C R, p=0,028$; after $C R, p=0,046)$, but other cardiopulmonary exercise capacity before and after $C R$ was not different between the groups. $\mathrm{HR}_{\text {rest }}(p<0,001)$, maximal metabolic equivalents (METs, $p<0,001$ ), total exercise duration (TED, $p<0,001$ ), and maximal oxygen consumption $\left(\mathrm{VO}_{2 \max }, \mathrm{p}<0,001\right) \mathrm{im}$ proved significantly in the obese and non-obese groups after CR. No difference in the change in the cardiopulmonary exercise capacity rate was detected between the groups. CR may improve functional capacity in patients who suffered AMI regardless of their obesity. ${ }^{21}$ 
A number of other CPET parameters may be inproved folllowing comprehensice exercise-based training program in patients with coronary artery disease. Heart rate recovery after 1 minute (HRR1) reflects parasympathetic activity after exercise training. HRR1 improves after 36 sessions ( 12 weeks, 3 times per week) exercise training, as reported by Dimopoulos et.al in a small study that included only 29 patients with heart failure who took part in a CR program. ${ }^{22}$ Our study extends this data on patients following acute $\mathrm{MI}$ treated with $\mathrm{pPCl}$ as we also showed improvement in HRR1 following exerciseprogram, which indicates good training response and higher contribution to the autonomic nervous system. $\mathrm{VE} / \mathrm{VCO}_{2}$ slope is also an important parameter for prognosis, expected to decrease after exercise training. ${ }^{23}$ Patients with a VE/ $/ \mathrm{VCO}_{2}$ slope exceeding 55 had a 2 year mortality of $65 \%$ reported as reported by the study by Francis and co-authors. ${ }^{14}$ For the reasons that are not clear, our data failed to show improvement in VE/VCO2 slope after training.

Study limitations. The major limitation of the present is relatively small number of patients.

\section{Conclusions}

Very short-term exercise training in patients with acute $\mathrm{Ml}$ treated with $\mathrm{pPCl}$ is safe and improves functional capacity, as well as test duration, work load and heart rate response.

\section{References}

1. Piepoli MF, Corrà U, Benzer W, et al. Secondary prevention through cardiac rehabilitation: physical activity counseling and exercise training. Key components of the position paper from the Cardiac Rehabilitation Section of the European Association of Cardiovascular Prevention and Rehabilitation. Eur Heart J. 2010; 31(16):1967-74.

2. Balady GJ, Williams M, Ades PA et al. Core Components of Cardiac Rehabilitation/ Secondary Prevention Programs: 2007 Update. A Scientific Statement From the American Heart Association Exercise, Cardiac Rehabilitation, and Prevention Committee, the Council on Clinical Cardiology; the Councils on Cardiovascular Nursing, Epidemiology and Prevention, and Nutrition, Physical Activity, and Metabolism; and the American Association of Cardiovascular and Pulmonary Rehabilitation. Circulation. 2007; 115 (20):2675-82.

3. Bjarnason-Wehrens B, Halle M. Exercise Training in Cardiac Rehabilitation. In: Niebauer J, ed. Cardiac Rehabilitation Manual. London: Springer - Verlang: 2011. p. 89-119.

4. Wenger NK. Curent status of cardiac rehabilitation. J Am Coll Cardiol. 2008; 51 (17): 1619-31.

5. Hansen D, Dendale P, Berger J, Meeusen R. Rehabilitation in cardiac patients. What do we know about training modalities? Sports Med. 2005; 35(12):1063-84.

6. American Association for Cardiovascular and Pulmonary Rehabilitation. Guidelines for Cardiac Rehabilitation and Secondary
Prevention Programs. $4^{\text {th }}$ Edition. Champaign, IL: Human Kinetics; 2004(2):5-18

7. Mezzani A, Hamm LF, Jones AM, McBride PE, at al. Aerobic exercise intensity assessment and prescription in cardiac rehabilitation: a joint position statement of the European Association for Cardiovascular Prevention and Rehabilitation, the American Association of Cardiovascular and Pulmonary Rehabilitation and the Canadian Association of Cardiac Rehabilitation. Eur J Prev Cardiol 2012. 20(3) 442-467

8. Balady G, Arena R, Sietsema K, et al. Clinician's Guide to Cardiopulmonary Exercise Testing in Adults. A Scientific Statement From the American Heart Association. Circulation. 2010; 122(2):191-225.

9. Wasserman K, Hansen JE, Sue DY, et al. Principles of Exercise Testing and Interpretation. 4th ed. Philadelphia: Lippincott Williams \& Wilkins; 2005, pp.111-132

10. Guazzi M, Adams V, Conraads V, et al. Clinical recommendations for cardiopulmonary exercise testing data assessment in specific patient populations. Circulation. 2012; 126 (18): 2261-74.

11. Schmid JP, Zurek M, Saner H. Chronotropic incompetence predicts impaired response to exercise training in heart failure patients with sinus rhythm. Eur J Prev Cardiol. 2013; 20(4):585-92.

12. Ades PA, Savage PD, Brawner CA, et al. Aerobic Capacity in Patients Entering Cardiac Rehabilitation. Circulation. 2006; 113:2706-12.

13. Savage PD, Antkowiak M, Ades PA. Failure to Improve Cardiopulmonary Fitness in Cardiac Rehabilitation. J Cardiopulm Rehabil Prev. 2009; 29(5):284-91.

14. Francis DP, Shamim W, Davies LC, et al. Cardiopulmonary exercise testing for prognosis in chronic heart failure. Continuosis and independent prognostic value from VE/VCO2 slope and peak VO2. Eur Heart J. 2000; 21(2):154-61.

15. Piepoli MF, Davos C, Francis DP, et al. Exercise training metaanalysis of trials in patients with chronic heart failure (ExTraMATCH). BMJ. 2004;328:189.

16. Gremeaux V, Duclay J, Deley G, et al. Does eccentric endurance training improve walking capacity in patients with coronary artery disease? A randomized controlled pilot study. Clin Rehabil. 2010; 24(7):590-9.

17. Bjarnason-Wehrens B, Predel HG, Graf C, et al. Improvement of physical performance and aerobic capacity mediated by a novel 4-week ambulatory cardiac rehabilitation program. Z Kardiol.1999; 88(2):113-22.

18. Xanthos PD, Gordon BA, Kingsley MI. Implementing resistance training in the rehabilitation of coronary heart disease: A systematic review and meta-analysis. Int J Cardiol. 2017;230: 493-508.

19. Che L, Wang LM, Jiang JF, et al. Effects of early submaximal cardiopulmonary exercise test and cardiac rehabilitation for patients with acute myocardial infarction after percutaneous coronary intervention: a comparative study. Zhonqhua Yi Xue Za Zhi. 2008; 88(26):1820-3.

20. CJ, Milani RV. Cardiac Rehabilitation Update 2008-Biological, Psychological and Clinical Benefits. US Cardiology. 2008; 5(1):72-76.

21. Lim SK, Han JY, Choe YR. Comparison of the Effects of Cardiac Rehabilitation Between Obese and Non-obese Patients After Acute Myocardial Infarction. Ann Rehabil Med. 2016;40(5):924932.

22. Dimopoulos S, Anastasiou-Nana M, Sakellariou D, et al. Effects of exercise rehabilitation program on heart rate recovery in patients with chronic heart failure. Eur J Cardiovasc Prev Rehabil. 2006;13 (1):67-73.

23. Arena R, Myers J, Abella J, et al. Development of a ventilatory classification system in patients with heart failure. Circulation. 2007; 115(18): 2410-17. 


\section{Sažetak \\ Uticaj kratkih programa bolničke kardiološke rehabilitacije kod pacijenata sa akutnim infarktom miokarda lečenih primarnom perkutanom koronarnom intervencijom}

Dejan Spiroski ${ }^{1}$, Mojsije Andjić ${ }^{1}$, Ivana Burazor ${ }^{1}$, Slavica Stevović ${ }^{1}$, Zoran Ćosić ${ }^{1}$, Olivera Ilić Stojanović ${ }^{1}$, Milica Lazović ${ }^{1,2}$, Ana Djordjević Dikić, 3 , Marija Zdravković, Dragan Lović, Branko Beleslin ${ }^{2,3}$

${ }^{1}$ Institut za rehabilitaciju, Beograd, Srbija, ${ }^{2}$ Medicinski fakultet Univerziteta u Beogradu, Beograd, Srbija, ${ }^{3}$ Klinika za kardiologiju Klinički centar Srbije, Beograd, Srbija, ${ }^{4}$ Kliničko bolnički centar Bežanijska kosa, Beograd, Srbija, ${ }^{5}$ Klinika za interne bolesti Inter Medica, Niš, Srbija

Uvod: Rehabilitacija zasnovana na vežbanju je važan deo lečenja pacijenata nakon akutnog infarkta miokarda (IM). Međutim, veoma su oskudni podaci o efektima kratkoročnih programa fizičke aktivnosti kod pacijenata sa akutnim $I M$ koji su lečeni primarnom perkutanom koronarnom intervencijom (pPCI). Cilj ovog rada je bio da se evaluiraju efekte kratkotrajnih programa fizičke aktivnosti na parametre kardiopulmonalnog testa opterećenja (KPTO) kod pacijenata nakon akutnog IM lečenih ( $p P C I)$.

Metode: Ispitivali smo 40 pacijenata sa IM lečenih pPCI-om koji su upućeni u našu ustanovu radi sprovođenja rehabilitacije. Studijska populacija se sastojala od 39 muškaraca i 1 žene (starosne dobi 50,60 \pm 8,40 godina, ejekcione frakcije leve komore, 53,05 $\pm 6,74 \%$ ), koji su učestvovali u 3 nedeljnom programu kardiološke rehabilitacije. Program se sastojao od vožnje bicikle 7 puta nedeljno i svakodnevnog hodanja u trajanju od 45 minuta na intenzitetu od $70-80 \%$ individualne maksimalne srčane frekvence. Svi pacijentima je urađen simptomima ograničen KPTO na biciklergometru po ramp protokolu od $10 \mathrm{~W} / \mathrm{min}$. KPTO je takođe rađen nakon sprovedenog programa kardiološke rehabilitacije.

Rezultati: Nakon 3 nedeljnog programa kardiološke rehabilitacije zasnovanog na vežbanju poboljšana je toleran-

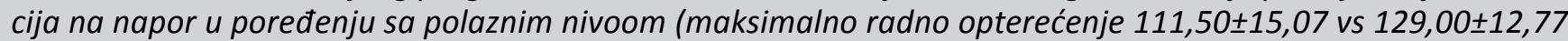
wati, $p<0,001)$, kao i maksimalni odnos disajne razmene $(1,02 \pm 0,10$ vs $1,08 \pm 0,13, p<0,05)$. Maksimalna vrednost sistolnog krvnog pritiska, srčana frekvenca, maksimalna i 1 minut nakon odmora, takođe su poboljšani. Najznačajnije poboljšanje je zabeleženo kod maksimalne VO2 $(18,17 \pm 3,30$ vs $20,64 \pm 3,27 \mathrm{ml} / \mathrm{kg} / \mathrm{min}, p<0,001)$, maksimalne VCO2 $(1,65 \pm 0,28$ vs $1,96 \pm 0,25 p<0,001)$, maksimalne ventilacije $(48,61 \pm 10,70$ vs $57,27 \pm 9,85 \mathrm{~L} / \mathrm{min}, p<0,001) i$ maksimalnog kiseoničnog pulsa $(14,16 \pm 2,62$ vs $60,18 \pm 14,19$ ml/otkucaj, $p<0,05)$. Tokom sprovođenja programa rehabilitacije nisu zabeleženi značajni neželjeni kardiološki događaji.

Zaključak: Kratkoročni fizički trening kod kod pacijenata sa akutnim IM koji su lečeni pPCI je pre svega bezbedan, poboljšava funkcionalni kapacitet, kao i trajanje testa, stepen opterećenja i reakciju srčane frekvence.

Ključne reči: kardiopulmonalni test opterećenja, fizički trening, kardiološka rehabilitacija, infarkt miokarda. 